NBER WORKING PAPER SERIES

COMPENSATION IN THE NONPROFIT SECTOR

\author{
Christopher J. Ruhm \\ Carey Borkoski \\ Working Paper 7562 \\ http://www.nber.org/papers/w7562 \\ NATIONAL BUREAU OF ECONOMIC RESEARCH \\ 1050 Massachusetts Avenue \\ Cambridge, MA 02138 \\ February 2000
}

\begin{abstract}
We thank Richard Frank, H.E. Frech III, Dan Rosenbaum, Doug Staiger, and Burton Weisbrod for helpful comments and William Black for research assistance. Ruhm gratefully acknowledges financial support from the National Science Foundation (SES-9876511) and from an NBER faculty fellowship for the study of nonprofit institutions. The views expressed herein are those of the authors and are not necessarily those of the National Bureau of Economic Research.

(C) 2000 by Christopher J. Ruhm and Carey Borkoski. All rights reserved. Short sections of text, not to exceed two paragraphs, may be quoted without explicit permission provided that full credit, including (C) notice, is given to the source.
\end{abstract}


Compensation in the Nonprofit Sector

Christopher J. Ruhm and Carey Borkoski

NBER Working Paper No. 7562

February 2000

JEL No. J3, J4

\begin{abstract}
This analysis provides an in-depth investigation of the determinants of pay in the nonprofit sector. The main findings are as follows. First, holding constant individual characteristics, average weekly wages are 11 percent lower in nonprofit than for-profit jobs. However, this difference is entirely explained by the concentration of nonprofit employment in relatively low paid industries. Second, an accompanying longitudinal analysis, focusing on movements of workers between nonprofit and profit-seeking employers, suggests a nonprofit penalty of between 2 and 4 percent. Third, nonprofit workers in three specific industries (hospitals, nursing/personal care facilities, social services) earn as much or more than their for-profit counterparts. However, the effects of changing the type of employment varies substantially across the three industries. These results raise questions about several predominant models of nonprofit wage-setting.
\end{abstract}

Christopher J. Ruhm

Department of Economics

University of North Carolina at Greensboro

P.O. Box 26165

Greensboro, NC 27402-6165

and NBER

c_ruhm@uncg.edu
Carey Borkoski

Department of Economics

University of North Carolina at Greensboro

P.O. Box 26165

Greensboro, NC 27402-6165

ccborkos@uncg.edu 


\section{Compensation in the Nonprofit Sector}

Nonprofit enterprises are an increasingly important part of the American economy. Between 1980 and 1997, their fraction of GDP rose from 2.9 to 4.3 percent (Bureau of Economic Analysis, 1998) and the number of national nonprofit associations grew 54 percent (Bureau of the Census, 1998). Nonprofits utilize the majority of volunteer labor and account for a significant proportion of paid employment in some industries. Despite their growing significance, the compensation of persons employed by nonprofits remains poorly understood. There is little question that nonprofit workers receive lower average earnings than observably similar individuals working for profit-seeking companies. ${ }^{1}$ However, since the distribution of jobs and employee characteristics differs markedly, it is difficult to determine whether the wage disparities reflect some type of compensating differential or worker heterogeneity not accounted for in standard earnings regressions.

To address these issues, this analysis provides an in-depth investigation of the determinants of pay in the nonprofit sector. Our goal is to ascertain how the earnings of individuals employed by nonprofit enterprises compare to those of identical persons working in profit-seeking firms. We also include government workers in our sample, and separately control for this sector in our analysis, but do not focus on government pay differentials. ${ }^{2}$

Compensation in the nonprofit sector may deviate from that in for-profit companies for a variety of reasons. Since any single empirical strategy is unlikely to adequately account for these complexities, our investigation utilizes four complementary approaches. The first investigates

\footnotetext{
${ }^{1}$ For example, Preston (1989) indicates that nonprofit managers and professionals earn $18 \%$ percent lower hourly wages than their for-profit counterparts, after controlling for human capital characteristics and the (one-digit) industry of employment.

${ }^{2}$ Previous researchers (e.g. Krueger, 1988; Moulton, 1990; Belman and Heywood, 1993) have examined whether government workers are "overpaid" compared to private sector employees. We compare workers
} 
the size and pattern of the cross-sectional differentials. The second estimates how wages change when workers shift between nonprofit and for-profit jobs. The third considers the corresponding earnings progression for persons changing sectors following job displacements. ${ }^{3}$ The fourth focuses on workers in three narrowly defined industries - hospitals, nursing/personal care facilities, and social services - with a substantial mix of nonprofit and for-profit employment.

Our results indicate that nonprofit jobs are concentrated in a relatively small number of industries. This is important because the 11 percent pay penalty associated with nonprofit employment disappears once industry controls are added to the wage equation. Movements between nonprofit and profit-seeking enterprises continue to suggest lower pay in nonprofits, but the differentials are dramatically smaller than in the cross-sectional models. Moreover, within specific industries, nonprofit employment is often associated with earnings premiums.

\section{Relative Earnings in the Nonprofit Sector}

Nonprofit enterprises differ from profit-seeking firms in important ways. They are frequently exempt from corporate income taxes and receive preferential treatment in state contract procurement processes (Frank and Salkever, 1994). The key feature, however, is that they are barred from distributing net earnings. According to Hansmann (1980), nonprofits may therefore be economically efficient when the consumer is in a poor position to judge the prices, quantity, or quality of services delivered. ${ }^{4}$ This occurs because they have reduced incentives to raise prices or cut quality, since it is more difficult for those controlling the organization to benefit from the resulting increase in profitability. As a result, Hansmann and others (e.g. Easley

in nonprofit enterprises to those in profit-seeking firms, rather than government, because there is no reason to assume that government wages are determined by market forces.

${ }^{3}$ Krueger and Summers (1988) use a similar mix of strategies to study inter-industry wage differentials.

${ }^{4}$ Hansmann calls this "contract failure". A classic example occurs when the purchaser and recipient of the service are separated (e.g. when financial donations are redistributed, either directly or in-kind, to 
and O'Hara, 1983; Handy and Katz, 1998) emphasize that nonprofits will be prevalent in markets with asymmetric information because they help to solve the consumer trust problem.

The nondistribution constraint provides two reasons why compensation in nonprofit enterprises might exceed that in profit-seeking companies. First, managers may have less incentive to hold down wages since they do not gain from the resulting cost-reductions. This has been termed as "philanthropic wage-setting" by Feldstein (1971) or "attenuated property rights" by Frech III (1976). ${ }^{5}$ Second, nonprofits have less incentive to shirk on quality and therefore are likely to employ better quality workers. ${ }^{6}$

Conversely, some individuals may be willing to "donate" a portion of their paid labor to “socially responsible" nonprofit employers by working at reduced wages. ${ }^{7}$ The resulting nonprofit wage penalty will be reinforced if these enterprises attract persons placing a relatively high value on institution-specific fringe benefits (such as working conditions, or other nonmonetary factors) and a low value on money. ${ }^{8}$ Also, Lakdawall and Philipson (1998) postulate that nonprofits will be concentrated in more competitive and less profitable sectors of the economy, where the benefits of choosing the nonprofit form exceed the costs imposed by the

needy individuals in distant locations). Day care and nursing homes provide other examples of contract failure. In these cases, the recipients of services may have difficulty judging its quality.

${ }^{5}$ Feldstein argues that nonprofit hospitals pay relatively high wages due to "philanthropic wage-setting". Frech III emphasizes that "attenuated property rights" reduce the price of nonpecuniary amenities such as pleasant offices and short working hours, resulting in higher production costs.

${ }^{6}$ For instance, in Newhouse's (1970) model of nonprofit hospitals, managers maximize a utility function with quantity and cost as arguments, subject to a zero profit constraint. This leads them to choose the lowest cost method of production but to oversupply quality.

${ }^{7}$ A recent study of Cornell University graduates indicates that those working in "socially responsible" occupations or companies received substantially lower wages than their counterparts after controlling for sex, curriculum, and grade point average (Frank, 1996). Also, the vast majority of volunteer (unpaid) labor is employed by nonprofits (Steinberg, 1990).

${ }^{8}$ Rose-Ackerman (1996) points out that "ideologues" may accept lower pay for nonprofit work to receive greater certainty that their efforts achieve altruistic goals, rather than benefiting stock-holders. 
nondistribution constraint and other limitations of nonprofit status (e.g. the bar on equity financing). The increased competitiveness implies downwards pressure on wages. ${ }^{9}$

The factors suggest a complex interaction between the class of employer (nonprofit vs. for-profit) and relative earnings. If labor donations are the dominant influence, nonprofit workers are likely to earn less than their counterparts. This will also be true if nonprofits offer other positive compensating differentials, such as better working conditions, shorter work hours, or lower risk of job loss. The resulting wage penalty will probably be smaller within narrowly defined industries, however, since organizations engaged in the same activities are likely to generate fairly comparable social benefits and have similar working conditions. Nonprofit workers might even be paid more than others in the same industry due to "attenuated property rights" or "philanthropic wage-setting", or if nonprofit enterprises utilize relatively high quality labor. ${ }^{10}$ Conversely, the generation of social benefits is less likely to be linked to the category of jobs (e.g. clerical workers) than the type of enterprise, implying that the nonprofit differential may be little affected by the addition of occupation controls to the econometric model. ${ }^{11}$

Useful information may be obtained from persons switching between nonprofit and forprofit employees, since such changes automatically control for all individual time-invariant sources of heterogeneity. With exogenous turnover, explanations emphasizing donated labor, other compensating differentials, or greater competition in the nonprofit sector would predict wage growth for persons moving from nonprofit to profit-seeking enterprises; those focusing on

\footnotetext{
${ }^{9}$ Weisbrod (1988) believes that nonprofits arise when the government us unable to meet the demand for public goods (e.g. care for the medically indigent). This has no obvious predictions for wage-setting. ${ }^{10}$ This argument has been cogently made by Preston (1988). One important additional implication is that nonprofit premiums will be less likely within industries that are extremely competitive.

${ }^{11}$ However, Handy and Katz (1998) and Preston (1999) argue that the nonprofit gap will be greater for managers than blue collar workers, since the latter are further removed from the generation of social benefits. Easley and O'Hara (1983) similarly suggest that the nondistribution constraint will lead to
} 
philanthropic wage-setting or attenuated property rights would imply earnings reductions; whereas wages would not change if cross-sectional gaps result from differences in average worker quality. However, an important caveat is that the job turnover will frequently be endogenous. Of particular importance are voluntary job changes, which are more probable when they result in economic benefits. This issue is discussed in detail below.

\section{Previous Research}

Previous research on nonprofit compensation, summarized in Figure 1, yields ambiguous results. Early investigations (e.g. Johnston and Rudney, 1987; Shackett and Trapani, 1987; Preston, 1989) were hampered by the lack of information on the type of employer, requiring the researchers to impute nonprofit status. Notwithstanding this caveat, the cross-sectional results suggest a large nonprofit pay penalty, a portion of which may be due to unobserved heterogeneity. By contrast, DuMond's (1997) analysis of the 1994-1995 Current Population Survey (CPS) Outgoing Rotation Groups (ORG), which directly indicate nonprofit status, estimates a considerably smaller 6 to 11 percent wage gap, with relatively higher pay in nonprofits for women than men. ${ }^{12}$ Moreover, fixed-effect (FE) models - focusing on switches between for-profit and nonprofit employment - imply small ( 0 to 4 percent) and statistically insignificant wage gaps, suggesting that the cross-sectional differential results from disparities in individual characteristics or preferences that are transferable across jobs. ${ }^{13}$

relatively large pay reductions for nonprofit managers, although an alternative possibility is that philanthropic wage-setting will result in relatively high nonprofit compensation for them.

12 The regressions hold constant education, potential experience and its square, gender, and dummy variables for race, marital status, union membership, part-time employment and (in the models with the smallest gaps), one-digit industries and occupations.

${ }^{13}$ DuMond's results should be interpreted with caution because government workers have been deleted from his data set, and it is not clear how the FE models deal with transitions into or out of the public sector. Also, few respondents switch types of employment over the two years and some reported changes may be erroneous. Such measurement error is particularly problematic for FE models. 
A second strand of the literature, focusing on nonprofit differentials within narrowly defined industries, also obtains equivocal results. Weisbrod (1983) finds that public interest lawyers earn 20 percent less per year than those employed in the private sector, are aware of the lower earnings, and expect the difference to be permanent. He interprets this to indicate that the nonprofit gap is due to heterogeneity in preferences rather than worker quality. However, Goddeeris (1988) reanalyzes the same data and claims that the wage penalty actually reflects personal characteristics and that public interest attorneys earn no less than had they been employed by profit-seeking companies.

Research on the nursing home and day care industries is similarly inconclusive. Borjas, Frech III, and Ginsburg (1983) find that nonprofit nursing homes offer relatively generous pay and suggest that this represents rent-sharing due to attenuated property rights. Conversely, Holtmann and Idson (1993) claim the wage premium occurs because nonprofit nursing homes use higher quality labor and that registered nurses could actually increase their earnings by switching to for-profit nursing facilities. Preston (1988) shows that federally regulated nonprofit day care centers pay 5 to 10 percent more than corresponding for-profits (although no differential is observed for non-federally regulated centers) and interprets this as evidence of philanthropic wage-setting. However, Mocan and Viola (1997) uncover a statistically insignificant 4 percent nonprofit wage premium, with considerable dispersion depending on the type of ownership and the racial composition of the staff. ${ }^{14}$

Leete (forthcoming) considers both overall and within-industry differentials. Using 1990 Census data which (like recent waves of the CPS) explicitly identifies nonprofit status, she finds

\footnotetext{
${ }^{14}$ Roomkin and Weisbrod (1999) show that there is ambiguity even within industries. Using data for six managerial positions in hospitals, they find that nonprofits offer lower compensation in three jobs (chief executive officer, chief operating officer, and top patient care executive) but higher pay in three others (chief financial officer, top human resources executive, head of nursing services).
} 
that the addition of detailed controls for industry, occupation, or industry-occupation interactions eliminates the overall nonprofit differential. In detailed industries where there is a statistically significant pay disparity, nonprofit workers are as likely to obtain premiums as penalties. ${ }^{15}$

\section{Data and Methods}

Most of our analysis focuses on 25 to 55 year old respondents to the 1994-1998 Current Population Survey Outgoing Rotation Groups (ORG). ${ }^{16}$ The CPS is a nationally representative survey of roughly 50,000 households. Individuals are interviewed for four months, out of the sample for eight, and then return for four final months. The outgoing rotation groups include persons in the last of each of the four month segments, hereafter referred to as years 1 and $2 .{ }^{17}$ Our cross-sectional sample includes data for year 1. The longitudinal analysis refers to individuals for whom data are available in both years 1 and 2 (twelve months apart). Not all persons can be matched across years. For instance, individuals are not followed if they changed addresses between ORG surveys. Our match rate of 65 percent is similar to that obtained by other researchers (e.g. MacPherson and Hirsch, 1995) using equally stringent criteria. The procedures used to perform the matching are detailed in Appendix A.

The dependent variable is the natural log of weekly wages on the "main" job. ${ }^{18}$ Weekly rather than hourly earnings are used because the latter are likely to be measured with greater error. However, work hours are sometimes directly controlled for. We are primarily interested

\footnotetext{
${ }^{15}$ These conclusions need to be interpreted cautiously for several reasons. The hourly wages will be measured with considerable error, since they are estimated from data on annual incomes, weekly work hours, and weeks worked per year. It is also not obvious how the analysis treats individuals holding multiple jobs at a point in time or during the year. Moreover, the demographic characteristics may inadequately account for differences in worker quality and the detailed controls for industry-occupation interactions could absorb a portion of the nonprofit differential.

${ }^{16}$ Older and younger respondents are excluded to avoid the special experiences of persons making schoolto-work or work-to-retirement transitions.

${ }^{17}$ The outgoing rotation groups contain supplemental questions on weekly earnings and work hours not included in the regular monthly CPS.
} 
in the parameter estimates for a dummy variable indicating whether the main job is with a private nonprofit organization, rather than a for-profit company (the reference group) or the government. The econometric models also control for a quadratic in age and dummy variables for education (high school dropout, high school graduate, some college, college graduate, graduate degree), marital status (currently married, previously married, never married), race (white, black, other nonwhite), Hispanic origin, sex, residence in a metropolitan area, and the survey year. Some specifications add regressors for industry, occupation, or usual weekly work hours.

We also utilize the Displaced Worker Supplements (DWS) to the February 1994, 1996, and 1998 Current Population Surveys. The DWS contain retrospective information on persons permanently losing jobs during the preceding three years. Our sample includes individuals aged 25 to 55 (at the time of the interview) who were displaced due to a plant closure, slack work, or position/shift abolished. The regressors are the same for the cross-sectional models as for the ORG data, except that no information is available on weekly work hours. The retrospective nature of the DWS implies some differences in the longitudinal analysis, as discussed below.

Variable means are similar for the cross-sectional and panel ORG samples (see Appendix Table B.1). The main differences are that the matched individuals are slightly older, more educated, less often Hispanic, and considerably more likely to live in metropolitan areas. These disparities probably reflect patterns of mobility and employment stability. By contrast, the DWS job losers are relatively young, uneducated, infrequently married, and poorly paid. Most importantly, the DWS sample is quite small and few of the respondents were displaced from nonprofit employment. This substantially limits the scope of analysis using this data source. The cross-sectional wage regressions take the form:

\footnotetext{
${ }^{18}$ For multiple job-holders, the "main" job is the one at which the person usually works the most hours. If he/she works the same number of hours at two jobs, it is the position of longest employment.
} 


$$
\mathrm{W}_{\mathrm{i} 1}=\mathrm{X}_{\mathrm{i} 1} \beta+\mathrm{N}_{\mathrm{i} 1} \gamma+\varepsilon_{\mathrm{i} 1}
$$

where $\mathrm{W}_{\mathrm{i} 1}$ is the natural $\log$ of weekly wages for worker $\mathrm{i}$ in year $1, \mathrm{X}$ is the vector of control characteristics, $\mathrm{N}$ is a dummy variable indicating nonprofit employment, and $\varepsilon$ is the regression error term. ${ }^{19}$ The coefficient of key interest, $\hat{\gamma}$, shows the predicted difference in (log) wages between workers in nonprofit and profit-seeking enterprises. However, this provides a biased estimate of the nonprofit differential if $\operatorname{cov}\left(\mathrm{N}_{\mathrm{i} 1} \varepsilon_{\mathrm{i} 1}\right) \neq 0$, as will occur if the control variables do not completely account for systematic differences in the selection process into nonprofit jobs.

Decomposing the error term as $\varepsilon_{i t}=\mathrm{f}_{\mathrm{i}}+\mathrm{e}_{\mathrm{it}}$, where $\mathrm{f}_{\mathrm{i}}$ is an individual fixed-effect and $\mathrm{e}_{\mathrm{it}}$ an i.i.d. disturbance, $\hat{\gamma}$ will be inconsistent if $\mathrm{N}_{\mathrm{it}}$ and $\mathrm{f}_{\mathrm{i}}$ are correlated. We can take first-differences to eliminate this bias. Specifically, if $(\log )$ wages in year $t$ (where $t=1,2)$ are determined by:

$$
\mathrm{W}_{\mathrm{it}}=\mathrm{X}_{\mathrm{i}} \beta_{\mathrm{t}}+\mathrm{N}_{\mathrm{it}} \gamma+\mathrm{f}_{\mathrm{i}}+\mathrm{e}_{\mathrm{it}}
$$

we can difference away the fixed-effect through the wage-change equation

$$
\Delta \mathrm{W}_{\mathrm{i}}=\mathrm{X}_{\mathrm{i}} \beta+\Delta \mathrm{N}_{\mathrm{i}} \gamma+\mathrm{e}_{\mathrm{i}}
$$

where $\Delta \mathrm{W}_{\mathrm{i}}=\mathrm{W}_{\mathrm{i} 2}-\mathrm{W}_{\mathrm{i} 1}, \Delta \mathrm{N}_{\mathrm{i}}=\mathrm{N}_{\mathrm{i} 2}-\mathrm{N}_{\mathrm{i} 1}, \mathrm{e}_{\mathrm{i}}=\mathrm{e}_{\mathrm{i} 2}-\mathrm{e}_{\mathrm{i} 1}$, and $\beta=\beta_{2}-\beta_{1}{ }^{20}$

Equation (3) will still yield inconsistent estimates if $\operatorname{cov}\left(\Delta \mathrm{N}_{\mathrm{i}} \mathrm{e}_{\mathrm{i}}\right) \neq 0$. A possible reason is that job mobility is not random. Specifically, economically motivated turnover occurs when compensation is expected to increase, implying $\mathrm{E}\left(\mathrm{e}_{\mathrm{i}}\right)>0$. If nonprofit jobs are typically poorly paid, switches from for-profit to nonprofit positions (abbreviated by $P \rightarrow N$ ) most often involve

\footnotetext{
${ }^{19}$ The regressions also include a dummy variables for government employment.

${ }^{20}$ An alternative is to estimate (1) with the inclusion of person-specific intercepts. Such fixed-effect models yield virtually identical results to the wage change models presented below. One disadvantage of the fixed-effect specification is that it can not easily be accommodated to the DWS data, which do not provide predisplacement values for many of the included regressors. To obtain consistency across the ORG and DWS data sets, $X_{i}$, in equation (3), is measured at year 2. We do not control for the selection into employment in either years 1 or 2 because of the difficulty in obtaining plausible identifying restrictions. This failure will not bias the estimated nonprofit differential as long as the selection process is similar for persons working in nonprofit and for-profit enterprises.
} 
some combination of relatively low wages on the original employment or high compensation in the new one. The nonprofit differential estimated from such moves is therefore likely to be understated because the conditional expectation $\mathrm{E}\left(\mathrm{e}_{\mathrm{i}} \mid P \rightarrow N\right)$ exceeds the unconditional expectation $\mathrm{E}\left(\mathrm{e}_{\mathrm{i}}\right)$. The bias will probably be absent or smaller when considering moves from nonprofit to profit-seeking employers (denoted $N \rightarrow P$ ), if the latter generally offer higher pay.

It is therefore useful to estimate "asymmetric wage change" models which allow different effects of $N \rightarrow P$ and $P \rightarrow N$ and moves. Denoting these transitions by the dummy variables NP and PN, the asymmetric models take the form:

$$
\Delta \mathrm{W}_{\mathrm{i}}=\mathrm{X}_{\mathrm{i} 2} \beta+\mathrm{NP}_{\mathrm{i}} \gamma_{1}+\mathrm{PN}_{\mathrm{i}} \gamma_{2}+\mathrm{e}_{\mathrm{i}}
$$

Notice that (4) collapses to (3) if $\gamma_{2}=-\gamma_{1}$. Therefore, $\hat{\gamma}_{2}$ and $-\hat{\gamma}_{1}$ provide alternative estimates of the nonprofit differential. ${ }^{21}$

The transitions that follow displacements are more likely to be exogenous (there is no presumption that $E\left(e_{i}\right)>0$ ), since the job mobility is involuntary. This suggests that the wage changes experienced by dislocated workers provide an alternative way to surmount the problem of endogenous turnover. The estimating equations are altered slightly for this sample, reflecting the information in the DWS. Cross-sectional wage differentials are obtained from:

$$
W_{\text {id }}=X_{i} \beta+N_{i d} \gamma+\varepsilon_{\text {id }}
$$

where the subscript $d$ indicates the predisplacement job. The individual characteristics are measured at the survey date since data are not available at the time of displacement. Information on work hours is also unavailable. The wage change equations take the form:

$$
\mathrm{W}_{\text {is }}-\mathrm{W}_{\mathrm{id}}=\mathrm{X}_{\mathrm{i}} \beta+\left(\mathrm{N}_{\mathrm{is}}-\mathrm{N}_{\mathrm{id}}\right) \gamma+\mathrm{e}_{\mathrm{i}}
$$

\footnotetext{
${ }^{21}$ The models also allow for transitions into or out of government employment and compare the wage changes for $N \rightarrow P(P \rightarrow N)$ mobility to those of persons remaining in nonprofit (for-profit) jobs.
} 
where the s subscript indicates the survey date. A potential problem is that patterns of reeemployment need not occur randomly. For instance, persons losing nonprofit jobs might first look for similar positions and then, failing to find them, search in profit-seeking companies. If so, the observed $N \rightarrow P$ transitions could reflect dislocated individuals with relatively unfavorable readjustment experiences $\left(\mathrm{E}\left(\mathrm{e}_{\mathrm{i}} \mid N \rightarrow P\right)<\mathrm{E}\left(\mathrm{e}_{\mathrm{i}} \mid N \rightarrow N\right)\right)$ and the estimated nonprofit differentials could still be biased.

\section{The Distribution of Nonprofit Employment}

Nonprofit employment is concentrated in a small set of industries and (to a lesser extent) occupations. This is illustrated in Tables 1 and 2. The first column of each table displays the industry (occupation) composition of all employment. The second presents the corresponding distribution of nonprofit jobs. The third and fourth columns indicate the share of employment in the specific industry (occupation) accounted for by nonprofit and profit-seeking organizations, with government the residual category. For example, the first row of Table 1 shows that religious organizations account for 0.7 percent of all employment but 10.4 percent of all nonprofit jobs, and that 85 percent of employees in this industry claim to work for nonprofits, compared to 15 percent in profit-seeking organizations.

Nonprofit positions are concentrated in seven fairly narrowly defined industries hospitals, nursing/personal care facilities, social services, primary/secondary education, higher education, religious organizations, and other professional industries. These account for 26 percent of all jobs but 89 percent of nonprofit positions. Over half ( 55 percent) of nonprofit employment is located in just three industries - hospitals, social services, and religious organizations - that are responsible for only 8 percent of all jobs. The share of nonprofit employment in these industries ranges from 34 to 85 percent, compared to an economy-wide average of under 6 percent. By contrast, there is virtually no nonprofit involvement in the 
transportation, personal/business services, wholesale/retail trade, manufacturing, public administration, agriculture, construction, or mining sectors. These industries are responsible for almost two-thirds (66 percent) of all employment but just 6 percent of nonprofit jobs.

Nonprofit jobs are more dispersed across occupations. Nevertheless, six categories health professionals, educators, other professionals, health technicians, administrative support workers, and service occupations - account for 92 percent of nonprofit employment (versus 60 percent of all jobs). Three of these - health professionals, educators, and health technicians employ 37 percent of nonprofit workers, compared to 12 percent of overall employment. Nonprofits are virtually absent from the sales, laborer, and transportation occupations that employ a large share of the working population.

Some of the econometric estimates below include dummy variables for the aforementioned seven specific industries or six occupations. This contrasts with some previous researchers (e.g. Preston, 1989 or DuMond, 1997) who control only for broad (one-digit) industries and occupations, or with Leete (forthcoming) who includes as many as 20,000 industry-occupation interactions. Within broad industries or occupations there is substantial heterogeneity in the prevalence of nonprofit activity. Conversely, extremely detailed industryoccupation interactions could absorb much of the nonprofit "effect", since many cells are dominated by a single class of employer.

The type of employment is reported by survey respondents, raising the possibility of classification error. There is little reason to believe that government or for-profit workers frequently misreport the class of employer. ${ }^{22}$ By contrast, nonprofit employment appears to be substantially undercounted. A careful analysis by the Hodgkinson, et al. (1996) indicates that

\footnotetext{
${ }^{22}$ For example, 100 percent of respondents in public administration report holding government jobs and 99 percent of those in the wholesale/retail trade or manufacturing industries claim for-profit employment.
} 
nonprofits constitute 6.7 percent of the paid work force in 1994. Conversely, only 5.7 percent of the ORG sample claim this type of employment, suggesting that around 18 percent of those in nonprofit jobs erroneously report holding for-profit positions. An identical 18 percent error rate is obtained by assuming that 100 percent of employment in religious organization is nonprofit, compared to the 85.1 percent reported by ORG respondents. ${ }^{23}$ Such classification errors will generally cause the observed wage gaps to be smaller than the actual differentials, since some nonprofit jobs are averaged in with for-profit positions. We return to this issue below.

\section{Cross-Sectional Wage Differentials}

We begin our empirical analysis by examining cross-sectional wage differentials for the ORG sample (in year 1). ${ }^{24}$ The top panel of Table 3 displays the mean weekly earnings of nonprofit, for-profit, and government workers in selected industries and occupations. Nonprofit workers earn 3 percent less than those in profit-seeking firms (while government employees receive 11 percent higher pay). However, within many narrow industries, there is a nonprofit premium - 10 percent in education, 11 percent in hospitals, 14 percent in nursing/personal care facilities, and 18 percent in social services. The major exception is a 7 percent wage gap in other professional industries, a diverse category likely to exhibit considerable heterogeneity between nonprofit and profit-seeking organizations. The overall wage gap combined with intra-industry premiums reflects the concentration of nonprofit jobs in low paid sectors such as social services and religious organizations. Nonprofit workers also frequently earn more than their for-profit

\footnotetext{
${ }^{23}$ The 34 percent of hospital workers claiming nonprofit affiliation appears low, given that around 65 percent of acute care hospital beds are in nonprofits. But this industry category also includes psychiatric hospitals, rehabilitation facilities, and post-acute care hospitals, that are heavily for-profit. Hodgkinson, et al. (1996) estimate that hospitals accounted for 33.7 percent of nonprofit employment in 1994, somewhat higher than the proportion in Table 1 (29.9 percent) which covers the 1994-1998 period. However, the hospital share of nonprofit jobs has been trending sharply down, suggesting that nonprofit hospital positions are only modestly more understated in our sample than is other nonprofit employment. ${ }^{24}$ Similar results are obtained for year 2.
} 
counterparts in the same occupation (e.g. 1, 7, and 5 percent for health professions, educators, and health technicians).

The disparities in average earnings may reflect individual heterogeneity, rather than differences in the pay determination process used by nonprofits. The bottom panel of Table 3 lends support to this possibility. Nonprofit and for-profit workers are equally likely to be married or live in metropolitan areas, but the former are slightly older, much more educated, almost twice as likely to be female, work fewer hours, and are less likely to be of Hispanic origin. Some of these differences (e.g. age and education) are likely to increase the relative wages of nonprofit workers while others (sex, Hispanic origin, and work hours) probably reduce them. Econometric analysis is needed to disentangle these effects.

Table 4 displays the coefficient on nonprofit status from regressions of equation (1). Each cell presents results for a separate specification. All of the models control for the survey year, age, marital status, race/ethnicity, education, metropolitan residence, and public sector employment. Columns (b), (d), and (e) add dummy variables for the seven industry categories; specifications (c) and (d) hold constant the six occupation groups; model (e) also accounts for usual weekly work hours. The employment characteristics refer to the "main" CPS job.

Nonprofit employment is associated with an 11 percent wage penalty, controlling for individual attributes but not industry or occupation. This is consistent with the differentials obtained by other researchers (e.g. Preston, 1989; DuMond, 1997). Adding the vector of occupation variables modestly increases the gap (to 14 percent). Conversely, including industry controls virtually eliminates the wage penalty (model b) and when work hours are also held constant (column e), the average nonprofit job is predicted to pay a slight (1 percent) premium. ${ }^{25}$

\footnotetext{
${ }^{25}$ Information on work hours is missing for around 6 percent of respondents. To avoid excluding these individuals, they are assigned a value of zero work hours and a dummy variable for missing hours is
} 
These results imply that nonprofit employment is concentrated in low paying industries and that observationally equivalent nonprofit and for-profit workers in the same industry receive identical wages. $^{26}$ Leete (forthcoming) has recently obtained a similar result. However, to eliminate the cross-sectional differential, she controlled for 226 (3-digit) industries and 206 occupations or (in many specifications) around 20,000 industry-occupation interactions. This contrasts with just 7 industries (and no occupations) in this analysis.

The average wage gaps conceal significant differences across demographic groups, with relatively high nonprofit earnings received by females, blacks, and Hispanics. The nonprofit differential in specification (a) is $-7,-2$, and -7 percent for these groups, versus -20 percent for males and -13 percent for whites. Holding industry and work hours constant (column e) shrinks but does not eliminate the disparities -women, blacks and Hispanics receive 3, 7, and 6 percent nonprofit premiums, compared to no differential for whites and a 3 percent penalty for males. ${ }^{27}$

As mentioned, these results may understate the nonprofit pay differential because some persons employed by nonprofits erroneously report working for profit-seeking organizations. A simplified version of the formula derived by Leete (forthcoming) shows that the ratio of the observed to actual gap in $\log$ wages $(\mathrm{G})$ is:

$$
\mathrm{G}=1-\frac{\phi \rho}{\phi \rho+(1-\rho)}
$$

included. However, the results are very similar when these persons are deleted from the sample. Models were also estimated with weekly work hours controlled for but without industry variables. These yield an overall nonprofit differential of 5.7 percent, with a standard error of 0.4 percent.

${ }^{26}$ Weekly earnings are top-coded at $\$ 1,920$ in 1994-1997 and \$2,880 in 1998. The top-coding affects 1.6 percent of workers in for-profit companies and 1.4 percent in nonprofit enterprises. Two sets of crosssectional models were estimated to provide a crude test of bias due to censoring. The first deletes observations with top-coded wage. In the second, persons with top-coded values were assigned earnings equal to twice the censored amount (i.e. $\$ 3,840$ through 1997 and $\$ 5,760$ in 1998). The overall nonprofit wage penalty (without controls for industry, occupation or work hours) is estimated to be 11 percent in the first model and 12 percent in the second. Both are close to the corresponding estimate in Table 4. 
where $\rho$ is the employment share of nonprofits and $\phi$ is the reporting error rate among nonprofit workers. Evidence presented in section 4 suggests that $\rho=.067$ and $\phi=.18$. Substituting these values into equation (7) indicates that the observed wage differential is 98.7 percent as large as the actual gap, implying that the preceding results only very slightly understate the nonprofit gap.

\section{Wage Changes for the ORG Panel Sample}

We next investigate wage changes between years 1 and 2 for the ORG panel sample. A potential problem is that some reported movements from nonprofit to for-profit jobs (or the reverse) probably reflect classification error. Most obviously, this occurs if respondents not switching jobs misreport the employer type in one of the two years. ${ }^{28}$ The resulting measurement error introduces noise and will attenuate the estimated nonprofit coefficients. For this reason, we only set the dummy variables indicating changes in the class of employer to one when the respondent states that such a switch has occurred and reports moving to either a new 3digit industry or occupation. Requiring a change in industry or occupation makes it much more likely that a job transition has taken place, substantially reducing the classification bias.

Table 5 documents the pattern of earnings changes. The first column shows the average growth in $(\log )$ wages between years 1 and 2 . The second and third columns provide sample means for respondents making $N \rightarrow P$ and $P \rightarrow N$ transitions. Earnings rise faster for persons switching from nonprofit to for-profit jobs than for those making the reverse move (11 versus 5 percent), suggesting lower pay in the nonprofit sector after controlling for transferable individual characteristics. However, there is no difference for females or blacks, which further hints that the nonprofit sector offers them comparatively favorable employment opportunities.

\footnotetext{
${ }^{27}$ Preston (1990) argues that the over-representation of females in nonprofits is entirely due to higher compensation received in these jobs. She does not perform a corresponding analysis for nonwhites. ${ }^{28}$ Reported changes in employment type could be dominated by classification error even if most respondents accurately indicate the class of employer.
} 
The econometric estimates are summarized in Table 6. Model (a) refers to an equation without controls for industry or work hours; specification (b) adds the seven industry dummy variables; column (c) also holds constant weekly work hours. The first three columns refer to cross-sectional wage regressions corresponding to equation (1). These results, which are virtually identical to corresponding specifications in Table 4, provide a baseline comparison for the wage change equations presented in the next five columns. As mentioned, the symmetric models constrain the change in relative wages to be of equal magnitude for $P \rightarrow N$ and $N \rightarrow P$ moves, whereas the asymmetric specifications do not. ${ }^{29}$

The symmetric first difference models reveal an overall nonprofit wage gap averaging between 2 and 3 percent, with relatively high earnings once again received by females and blacks (but not Hispanics) employed in nonprofit jobs. The estimated nonprofit differentials are insensitive to the inclusion of controls for industry or work hours (see models a through c), which is expected since the change equations automatically account for time-invariant individual effects. The asymmetric models predict a 4 percent average increase in weekly wages for persons making $N \rightarrow P$ moves, compared to a 2 percent decline for $P \rightarrow N$ transitions. This difference is anticipated if the $P \rightarrow N$ switches understate the nonprofit penalty, as discussed above. However, the disparities are small and statistically insignificant for all groups, indicating that there is little cost to imposing the assumption of symmetric wage changes.

\section{Displaced Workers}

Table 7 summarizes the results for displaced workers. As noted, nonprofit workers rarely lose jobs so this is not a representative sample of either all employees or job changers. The four columns labeled "transition hazard rates" show the probability of entering the destination

\footnotetext{
29 The asymmetric model presented in the table includes controls for industries and work hours. Similar
} results are obtained in specifications without these regressors. 
employer type conditional on initial status. It is noteworthy that $P \rightarrow N$ transitions almost never occur. Only 3 percent of persons displaced from for-profit companies work for nonprofits at the survey date, compared to 92 percent by profit-seeking firms (and 5 percent in government positions). The majority (57 percent) of those losing nonprofit jobs also enter for-profit employment, versus 29 percent who remain with nonprofits (and 14 percent in government jobs).

The cross-sectional equations indicate broadly similar predisplacement earnings for persons terminated from nonprofit and for-profit positions. There is some suggestion of a small nonprofit penalty, but this disappears when industry controls are included (compare columns a and b) and the nonprofit coefficient is never significant. The wage change equations also supply some indication of a nonprofit penalty in the absence of industry regressors; however, this is again eliminated by adding industry covariates, and the parameters are imprecisely estimated. Small sample sizes, particularly for nonwhites, and nonrandomness of the displacement process imply that these results should be interpreted with caution. Generally, the small overall nonprofit differentials, combined with more favorable effects for females and blacks than for males or whites, are consistent with the results obtained using the ORG data.

\section{Intra-Industry Wage Differentials}

Table 8 displays the findings of cross-sectional and wage change equations for ORG respondents working in three specific industries - hospitals, nursing/personal care facilities, and social services. Together, these industries account for 49 percent of nonprofit employment but each also has substantial involvement by for-profit companies. ${ }^{30}$ Cross-sectional regressions, corresponding to equation (1), were run for the full sample and for workers matched in years 1 and 2. Symmetric wage change equations were also estimated for persons employed in the same 
industry in both survey years. This sample restriction avoids confounding the effects of industry mobility with those resulting from changes in the type of employer. Specification (b) controls for work hours, whereas specification (a) does not. Since the sample for each regression is limited to a single industry, none of the models include industry covariates.

The cross-sectional results suggest the presence of nonprofit wage premiums within the three narrowly defined industries. Nonprofit hospital workers earn a statistically significant 3 to 7 percent more than their peers. An even larger 4 to 11 percent differential is obtained in the social services, while nonprofit nursing facilities offer a 2 to 5 percent pay premium.

Interestingly, models estimated for subsamples stratified by race and sex (not shown), provide no consistent evidence of higher relative nonprofit earnings for women or minorities than for men or whites, suggesting that the relatively favorable "effects" observed above may have been due to inadequately controlling for the industrial composition of nonprofit employment. ${ }^{31}$

The first difference models indicate that switching between nonprofit and profit-seeking employers has dramatically different effects on wage growth across the three industries. The predicted pay progression of hospital workers is unaffected by $N \rightarrow P$ transitions; whereas, similar mobility increases the expected earnings growth of nursing homes employees by a statistically significant 18 percent while lowering the predicted wage increases of social service workers by an insignificant 4 percent.

\footnotetext{
${ }^{30}$ Education and religious organizations employ around a quarter of the nonprofit labor force but have limited participation by for-profits. Other professional industries account for an eighth of nonprofit jobs but are extremely diverse and dominated by profit-seeking enterprises.

${ }^{31}$ The estimated nonprofit differential (in specification b) is 5.8, 6.3, and -0.9 percent for males in the hospital, nursing home, and social services industries versus $2.5,4.7$, and 13.4 percent for females. The differentials are 3.1, 4.4, and 11.0 percent for whites and 4.1, 7.1, and 11.3 percent for blacks.
} 


\section{Discussion}

The econometric analysis yields five main conclusions. First, holding constant individual characteristics, average weekly wages are 11 percent lower in nonprofit than for-profit jobs. However, the inclusion of industry controls eliminates the pay gap and, if anything, nonprofit workers receive a small premium when differences in work hours are also accounted for. By contrast, the differential is unrelated to the occupational distribution of nonprofit jobs. Second, the wage changes experienced by persons switching types of employers suggest a nonprofit penalty of between 2 and 4 percent. Third, the nonprofit sector offers relatively high pay to females and blacks, although this is again largely explained by industry differences in the composition of nonprofit employment. Fourth, the nonprofit differentials estimated for job losers are generally consistent with those for other individuals, although small sample sizes and nonrandomness of the displacement process require these results to be interpreted cautiously. Fifth, nonprofit workers in hospitals, nursing/personal care facilities, and social services earn at least as much as their observably similar counterparts, but the effect of changing between nonprofit and for-profit employment varies substantially across the three industries.

What do these results tell us about wage-setting in the nonprofit sector? The virtual absence of nonprofit wage penalty, after controlling for industry, suggests that the scope of labor donations to nonprofits by paid employees is limited. However, movements from nonprofit to for-profit jobs are associated with relative wage increases of around 4 percent, raising the possibility of modest amounts of donated labor. Differences in worker quality or philanthropic wage-setting are also unlikely to predominate in explaining the observed patterns of pay. If lower nonprofit wages resulted from the use of poor quality employees, the differential would be robust to the inclusion of industry controls. And neither explanation predicts wage increases for individuals moving from nonprofit to profit-seeking enterprises. Nevertheless, quality 
differences or attenuated property rights may be relevant in some sectors. For instance, nonprofit nursing home workers earn more than their peers employed by profit-seekers and experience relative wage reductions when switching into for-profit jobs, as predicted by the rent-sharing model. However, the nonprofit premiums do not dissipate when hospital or social service workers make similar moves, suggesting that the higher initial wages result from transferable individual characteristics rather than the payment of rents.

The most important finding is that the low average nonprofit wages reflect the concentration of these jobs in low-paying industries. This could take place because disadvantaged groups (such as blacks and women) or low quality workers are selected into these sectors. In this case industry controls would absorb a portion of the "true" nonprofit differential. However, this seems unlikely. Models emphasizing restricted job availability (e.g. Bergmann, 1974) typically focus on occupations rather than industries and it is not obvious what mechanism might limit access to the latter, given the broad set of occupations they employ. The low wages might also occur if nonprofits locate in relatively competitive industries. Many industries with high nonprofit shares are quite competitive, justifying further investigation of the role of market structure in determining the patterns of pay. ${ }^{32}$

An alternative explanation is that nonprofit jobs offer low pay because they are prevalent in industries offering positive compensating differentials. If for-profit positions in the same industries provide similar compensating differentials, no pay gap would be anticipated once industries are controlled for. The relatively small wage changes associated with moves between

\footnotetext{
32 Four-firm sales concentration ratios in the nursing/personal care facility and social service industries were 14.8, and 7.9 percent in 1992 (Bureau of the Census, 1995). For comparison, Scherer and Ross (1990) indicate four-firm sales concentration ratios of 20 percent or higher for more than 80 percent of U.S. manufacturing industries in 1982. However, the relevant market is likely to be more localized for service than manufacturing industries, so this comparison may overstate the competitiveness of the
} 
nonprofit and profit-seeking employers might then occur because job changers typically remain in the same industry or move to ones offering similar nonwage benefits.

Most obviously, nonprofits could disproportionately be represented in industries performing "socially desirable" activities (e.g. helping the sick), resulting in a willingness of workers to accept reduced compensation. This represents a variation of the labor donation hypothesis. However, the key distinction is that individuals care not about the type of the employer but rather about the goods or services they provide. When estimating the "pure" effect of nonprofit status, as distinct from other specific attributes of the employer, it is therefore appropriate to include industry controls.

Another reason for lower weekly wages is that nonprofit employees work fewer hours than their counterparts. An examination of work hours reveals the exact pattern hypothesized above. Specifically, in a cross-sectional equation (estimated by OLS) nonprofit employment is associated with a 1.7 per week reduction in work hours (with a standard error of .2 hours), holding constant individual characteristics. Controlling for industries reduces the differential to 0.4 hours, and switchs from for-profit to nonprofit employment (between years 1 and 2) are predicted to decrease them by just 0.2 work hours per week.

Direct evidence on other compensating differentials is difficult to obtain. DuMond (1997) indicates that pension and health insurance coverage (displacement rates) are relatively high (low) for persons employed by nonprofit enterprises. This is consistent with the existence of positive compensating differentials and makes it doubtful that nonprofits pay less because they locate in more competitive sectors. However, his analysis is not definitive since it does not 
control for individual characteristics or the industry of employment. ${ }^{33}$ Finally, Gonyea (1999) argues that nonprofit employers may be more sensitive to work-family issues, although the evidence cited supporting this position is quite limited.

${ }^{33}$ The March Current Population Survey Annual Demographic file, used by DuMond, does not identify the job providing the fringe benefits. This is problematic for persons holding multiple positions or changing employers during the year. 


\section{References}

Belman, Dale and John S. Heywood, "Job Attributes and Federal Wage Differentials" Industrial Relations, 32(1), Winter 1993, 148-157.

Bergmann, Barbara R., "Occupational Segregation, Wages, and Profits When Employers Discriminate by Race or Sex” Eastern Economic Journal, 1(2), April-July 1974, 103-110.

Borjas, George J., H.E. Frech III, Paul B. Ginsburg, "Property Rights and Wages: The Case of Nursing Homes" Journal of Human Resources, 17(2), 1983, 231-246.

Bureau of the Census, Statistical Abstract of the United States 1998, U.S. Department of Commerce, Economics and Statistics Administration, October 1998 (Table 1286).

Bureau of the Census. 1992 Census of Service Industries, "Establishment and Firm Size", SC92S-1. Washington, D.C., U.S. Government Printing Office, May 1995. (Downloaded from: http://www.census.gov/epcd/www/concentration.html, 9/14/99.)

Bureau of Economic Analysis, Survey of Current Business, U.S. Department of Commerce, Economics and Statistics Administration, August 1999 (Table 1.7).

DuMond, J. Michael. Wage Tradeoffs: An Analysis of the Nonprofit Sector and Local Amenities, unpublished Ph.D. dissertation, Florida State University, May 1997.

Easley, David and Maureen O'Hara. “The Economic Role of the Nonprofit Firm”, Bell Journal of Economics, 14, August 1983, 531-538.

Feldstein, Martin S. The Rising Cost of Hospital Care. Information Services Press: Washington, D.C., 1971

Frank, Richard G. and David S. Salkever. "Nonprofit Organizations in the Health Sector", Journal of Economic Perspectives 8(4), fall 1994, 129-144.

Frank, Robert H. "What Price the Moral High Ground?", Southern Economic Journal, 63, July 1996, 1-17.

Frech III, H.E. "The Property Rights Theory of the Firm: Empirical Estimates from a Natural Experiment", Journal of Political Economy 84(1), 1976, 143-152.

Goddeeris, John H. "Compensating Differentials and Self-Selection: An Application to Lawyers", Journal of Political Economy, 96(2), 1988, 411-428.

Gonyea, Judith G. “The Nonprofit Sector's Responsiveness to Work-Family Issues" Annuals of the Academy of Political and Social Science, 562(0), March 1999, 127-142.

Handy, Femida and Eliakim Katz. "The Wage Differential Between Nonprofit Institutions and Corporations: Getting More By Paying Less", Journal of Comparative Economics 26, 1998, 246-61. 
Hansmann, Henry B. "The Role of Nonprofit Enterprise" The Yale Law Journal 89(5), April 1980, 835-901.

Hodgkinson, Virginia Ann, Murray S. Weitzman, John A. Abrahams, Eric A. Crutchfield, and David R. Stevenson. Nonprofit Almanac: 1996-1997. San Francisco: Jossey-Bass Publishers, 1996.

Holtmann, A.G. and Todd L. Idson. "Wage Determination of Registered Nurses in Proprietary and Nonprofit Nursing Homes" Journal of Human Resources, 28(1), Winter 1993, 55-79.

Johnston, Denis and Gabriel Rudney. "Characteristics of Workers in Nonprofit Organizations", Monthly Labor Review, 110(7), July 1987, 28-33.

Krueger, Alan B. "Are Public Sector Workers Paid More Than Their Alternative Wage? Evidence from Longitudinal Data and Job Queues" in Richard B. Freeman and Casey Ichniowski (eds.) When Public Sector Workers Unionize. Chicago: University of Chicago Press (for the National Bureau of Economic Research), 1988, 217-240.

Krueger, Alan B. and Lawrence H. Summers. "Efficiency Wages and the Inter-industry Wage Structure" Econometrica 56(2), March 1988, 259-293.

Lakdawall, Darius and Tomas Philipson. "Nonprofit Competition and Production" NBER Working Paper No. 6377, January 1998.

Leete, Laura. "Whither the Nonprofit Wage Differential? Estimates From the 1990 Census" Journal of Labor Economics, forthcoming.

MacPherson, David A. and Barry T. Hirsch. "Wages and Gender Composition: Why Do Women's Jobs Pay Less?", Journal of Labor Economics, 13(3), July 1995, 426-471.

Mocan, Naci H. and Deborah Viola. "The Determinants of Child Care Workers' Wages and Compensation: Sectoral Difference, Human Capital, Race, Insiders and Outsiders" NBER Working Paper No. 6328, December 1997.

Moulton, Brent R. "A Reexamination of the Federal-Private Wage Differential in the United States", Journal of Labor Economics, 8(2), April 1990, 270-293.

Newhouse, Joseph P. "Towards a Theory of Nonprofit Institutions: An Economic Model of a Hospital”, American Economic Review, 60, March 1970, 64-74.

Preston, Anne E. "The Effects of Property Rights on Labor Costs of Nonprofit Firms: An Application to the Day Care Industry", Journal of Industrial Economics 36(3), March 1988, 337-350.

Preston, Anne E. "The Nonprofit Worker in a For-Profit World", Journal of Labor Economics 7(4), 1989, 438-463. 
Preston, Anne E. "Women in the White-Collar Nonprofit Sector: The Best Option or the Only Option?" Review of Economics and Statistics, 72(4), November 1990, 560-568.

Roomkin, Myron J. and Burton A. Weisbrod. "Managerial Compensation and Incentives in ForProfit and Nonprofit Hospitals", The Journal of Law, Economics, and Organization, 15(3), October 1999, 750-781.

Rose-Ackerman, Susan. "Altruism, Nonprofits, and Economic Theory", Journal of Economic Literature, 34(2), June 1996, 701-728.

Scherer, F.M. and David Ross. Industrial Market Structure and Economic Performance, $3^{\text {rd }}$ Edition. Boston: Houghton Mifflin Company, 1990.

Shackett, Joyce R. and Trapani, John M. "Earnings Differentials and Market Structure” Journal of Human Resources, 22(4), Fall 1987, 518-531.

Steinberg, Richard. "Labor Economics and the Nonprofit Sector: A Literature Review", Nonprofit and Voluntary Sector Quarterly, 19(2), Summer 1990, 151-169.

Weisbrod, Burton A. "Nonprofit and Proprietary Sector Behavior: Wage Differentials Among Lawyers", Journal of Labor Economics, 1(3), 1983, 246-263.

Weisbrod, Burton A. The Nonprofit Economy. Cambridge, MA: Harvard University Press, 1988 


\section{Appendix A: Construction of Longitudinal Sample from the ORG Files}

Households participate in the CPS for four months, followed by eight months out of the sample and then four final months in it. The outgoing rotation groups include respondents in the final months of each of the two periods (denoted years 1 and 2). The CPS contains household identifiers (ID codes) and record line numbers but not individual codes. Individuals from the same month in consecutive years can potentially be identified using the household ID codes and record line numbers. The household ID represents a permanent residence and does not follow families that relocate. The coding of the ID variable was changed from 12 to 15 characters in July of 1995, implying that households whose ORG months crossed this date could not be matched. Also, since different states sometimes use the same household ID, state (FIPS) codes are needed to uniquely identify the household.

The following procedure was used to create the ORG matched panel data set. First, individual cross-sectional data sets were created for each of the years 1994 through 1998. The samples were restricted to non-self employed persons working for pay and aged 25 through 55 . Second, the five annual data sets were merged and persons in time periods that were not potentially matchable, because of changes in coding the household ID, were deleted. This yielded a sample with 333,134 person-year observations, including 165,516 for year 1 and 167,618 at year 2 . The sample was then sorted by year, month, household ID, state, and record line. Several passes of the data were then used to limit the sample to cases where consecutive observations were one year apart and had the same calendar month, household ID, state code, and record line. This reduced the sample to 236,122 observations. To further insure that the matched observations referred to the same individual, we deleted cases where there was a change (between year 1 and 2) in sex or race, or more than a two year difference in age. (A two year age difference was allowed because the surveys could take place on different days of the month.) 
Finally, the matched pair was deleted if the first (second) observation was listed as the eighth (fourth) month in sample, rather than the reverse. These restrictions reduced the sample to 107,422 individuals $(214,844$ person-year observations), corresponding to 64.5 percent of the original sample and 64.9 percent of year 1 observations. 


\section{Appendix B}

Table B.1: Variable Means for Alternative Samples

\begin{tabular}{|c|c|c|c|}
\hline Variable & Cross-Section & Panel & Job Losers \\
\hline \multicolumn{4}{|l|}{ Employment Sector } \\
\hline Profit & .764 & .742 & .903 \\
\hline Nonprofit & .057 & .061 & .033 \\
\hline Government & .179 & .197 & .064 \\
\hline \multicolumn{4}{|l|}{ Industry } \\
\hline Religious Organizations & .007 & .007 & .002 \\
\hline Social Services & .022 & .021 & .012 \\
\hline Hospitals & .051 & .056 & .019 \\
\hline Higher Education & .025 & .025 & .015 \\
\hline Nursing/Personal Care Facilities & .015 & .014 & .006 \\
\hline Other Professional & .072 & .073 & .071 \\
\hline Primary/Secondary Education & .067 & .075 & .018 \\
\hline \multicolumn{4}{|l|}{ Occupation } \\
\hline Health Professional & .042 & .045 & .025 \\
\hline Health Technician & .016 & .018 & .007 \\
\hline Educator & .064 & .070 & .024 \\
\hline Other Professional & .207 & .215 & .200 \\
\hline Administrative Support & .156 & .164 & .157 \\
\hline Service Worker & .118 & .106 & .086 \\
\hline \multicolumn{4}{|l|}{ Weekly Earnings/Hours } \\
\hline Earnings & $\$ 581$ & $\$ 598$ & $\$ 527$ \\
\hline Work Hours & 40.5 & 40.7 & \\
\hline \multicolumn{4}{|l|}{ Education } \\
\hline High School Dropout & .097 & .082 & .103 \\
\hline High School Graduate & .331 & .330 & .328 \\
\hline Some College & .281 & .286 & .323 \\
\hline College Graduate & .198 & .204 & .181 \\
\hline Graduate Degree & .093 & .097 & .064 \\
\hline \multicolumn{4}{|l|}{ Marital Status } \\
\hline Currently Married & .655 & .700 & .614 \\
\hline Never Married & .185 & .158 & .203 \\
\hline \multicolumn{4}{|l|}{ Race/Ethnicity } \\
\hline Black & .120 & .112 & .094 \\
\hline Other Nonwhite & .045 & .041 & .043 \\
\hline Hispanic & .097 & .085 & .101 \\
\hline \multicolumn{4}{|l|}{ Other Characteristics } \\
\hline Age (years) & 38.7 & 39.3 & .376 \\
\hline Male & .524 & .518 & .580 \\
\hline Metropolitan Residence & .776 & .822 & .830 \\
\hline Sample Size & 301,208 & 107,422 & 5,381 \\
\hline
\end{tabular}


Note: See notes on Tables 1 and 2. All variable means are computed using CPS sampling weights. The cross-section includes respondents in year 1 of the 1994-1998 Current Populatoin Survey Outgoing Rotation Groups. The panel includes respondents for the same period who could be matched in the fourth months of years 1 and 2. Job losers include respondents to the 1994, 1996, and 1998 Displaced Worker Supplements to the February CPS for whom data were available on weekly wages in the predisplacement job and at the survey date. For the crosssection and panel samples, all variables are measured at year 1. For job losers, the means are for the survey date, except weekly wages and the sector, industry, and occupation of employment, where they refer to the predisplacement job. 
Figure 1: Previous Research on Nonprofit Earnings Differentials

\begin{tabular}{|c|c|c|c|}
\hline Study & Data & Results & Comments \\
\hline $\begin{array}{l}\text { Borjas } \\
\text { Frech III, } \\
\text { and } \\
\text { Ginsburg } \\
(1983)\end{array}$ & $\begin{array}{l}\text { 1973-74 National } \\
\text { Nursing Home } \\
\text { Survey }\end{array}$ & $\begin{array}{l}\text { Nursing home workers in religious- } \\
\text { affiliated nonprofits earn } 4 \% \text { less per } \\
\text { than those in for-profits; those in other } \\
\text { nonprofits receive an insignificant } 1.6 \% \\
\text { premium. Some evidence of higher } \\
\text { wages for homes with more generous } \\
\text { Medicaid reimbursement programs. }\end{array}$ & $\begin{array}{l}\text { Many results are } \\
\text { statistically insignificant } \\
\text { or sensitive to the choice } \\
\text { of specifications. }\end{array}$ \\
\hline $\begin{array}{l}\text { DuMond } \\
\text { (1997) }\end{array}$ & $\begin{array}{l}1995 \text { Current } \\
\text { Population Survey } \\
\text { Outgoing Rotation } \\
\text { Groups }\end{array}$ & $\begin{array}{l}\text { Nonprofit workers earn } 6 \% \text { (11\%) less } \\
\text { per hour than counterparts without (with) } \\
\text { controls for industry and occupation. } \\
\text { Larger differential for males (19\%) than } \\
\text { females }(0 \% \text { to } 5 \%) \text {. Gaps shrink to a } \\
\text { insignificant } 0 \% \text { to } 4 \% \text { in first-difference } \\
\text { models. Nonprofit workers have higher } \\
\text { pension/ health insurance coverage, } \\
\text { lower displacement rates. }\end{array}$ & $\begin{array}{l}\text { Not clear how } \\
\text { government workers are } \\
\text { treated. Limited sample } \\
\text { for wage change models. }\end{array}$ \\
\hline $\begin{array}{l}\text { Frank } \\
\text { (1996) }\end{array}$ & $\begin{array}{l}\text { Cornell } \\
\text { Employment } \\
\text { Survey and other } \\
\text { sources. }\end{array}$ & $\begin{array}{l}\text { Nonprofit differential in annual earnings } \\
\text { was }-59 \% \text { for recent Cornell graduates, } \\
\text { controlling for sex, GPA, and college } \\
\text { curriculum. Other evidence of negative } \\
\text { compensating differentials for working } \\
\text { for socially responsible employers. }\end{array}$ & $\begin{array}{l}\text { Small and } \\
\text { unrepresentative sample } \\
\text { in main analysis; few } \\
\text { controls. }\end{array}$ \\
\hline $\begin{array}{l}\text { Goddeeris } \\
\text { (1988) }\end{array}$ & $\begin{array}{l}\text { Nationally } \\
\text { representative } \\
\text { surveys of private } \\
\text { and public interest } \\
\text { lawyers in 1973/4. }\end{array}$ & $\begin{array}{l}\text { Public Interest (PIL) lawyers earn } 37 \% \\
\text { less than those in private firms but this is } \\
\text { entirely due to differences in } \\
\text { characteristics. They would earn no less } \\
\text { if they switched into the private sector. }\end{array}$ & $\begin{array}{l}\text { Sector definitions differ } \\
\text { from Weisbrod (1983). } \\
\text { Selection identified by } \\
\text { community size, political } \\
\text { activities/orientation. }\end{array}$ \\
\hline $\begin{array}{l}\text { Holtmann } \\
\text { and Idson } \\
(1993)\end{array}$ & $\begin{array}{l}\text { Registered nurses } \\
\text { in } 1985 \text { National } \\
\text { Nursing Home } \\
\text { Survey }\end{array}$ & $\begin{array}{l}\text { Nonprofits employ higher quality RNs. } \\
\text { OLS models reveal a } 3 \% \text { hourly wage } \\
\text { premium for RNs in nonprofit homes and } \\
\text { steeper experience/tenure profiles for } \\
\text { them. However, selectivity-corrected } \\
\text { models indicate that RNs in nonprofits } \\
\text { actually earn less than they would if } \\
\text { employed in for-profits. }\end{array}$ & $\begin{array}{l}\text { No distinction between } \\
\text { government and private } \\
\text { nonprofit nursing homes. } \\
\text { Identification restrictions } \\
\text { of selectivity-corrected } \\
\text { models are questionable. }\end{array}$ \\
\hline $\begin{array}{l}\text { Johnston } \\
\text { and Rudney } \\
(1987)\end{array}$ & $\begin{array}{l}1982 \text { Census of } \\
\text { Service Industries }\end{array}$ & $\begin{array}{l}\text { The average annual earnings of nonprofit } \\
\text { workers are } 21.5 \% \text { less than those } \\
\text { employed in for-profit firms. }\end{array}$ & $\begin{array}{l}\text { Hospitals, educational } \\
\text { institutions, and religious } \\
\text { organizations excluded. } \\
\text { No controls for individual } \\
\text { characteristics. }\end{array}$ \\
\hline $\begin{array}{l}\text { Leete } \\
\text { (forth- } \\
\text { coming) }\end{array}$ & $\begin{array}{l}\text { 1990 Census, Five } \\
\text { Percent Public } \\
\text { Use Microdata } \\
\text { Sample }\end{array}$ & $\begin{array}{l}\text { No overall nonprofit wage differential } \\
\text { after including detailed controls for } \\
\text { industry and occupation. Among } \\
\text { specified 3-digit industries with } \\
\text { statistically significant nonprofit } \\
\text { differentials, positive and negative } \\
\text { effects are equally likely. }\end{array}$ & $\begin{array}{l}\text { Estimated hourly wages } \\
\text { may be subject to } \\
\text { measurement error. } \\
\text { Extremely detailed } \\
\text { industry-occupation } \\
\text { interactions could absorb } \\
\text { nonprofit effects. }\end{array}$ \\
\hline
\end{tabular}


Figure 1 (continued)

\begin{tabular}{|c|c|c|c|}
\hline $\begin{array}{l}\text { Mocan and } \\
\text { Viola } \\
(1997)\end{array}$ & $\begin{array}{l}398 \text { child care } \\
\text { centers in } \mathrm{CA}, \\
\mathrm{CO}, \mathrm{CT}, \text { and } \mathrm{NC}\end{array}$ & $\begin{array}{l}\text { Nonprofit child care workers receive a } \\
\text { statistically insignificant } 4 \% \text { premium in } \\
\text { hourly wages; considerable variation by } \\
\text { type of nonprofit and worker. }\end{array}$ & $\begin{array}{l}\text { Extensive controls for } \\
\text { human capital, center } \\
\text { characteristics. }\end{array}$ \\
\hline $\begin{array}{l}\text { Preston } \\
\text { (1988) }\end{array}$ & $\begin{array}{l}\text { Abt Associates, } \\
\text { 1976-77 National } \\
\text { Day Care Center } \\
\text { Supply Study }\end{array}$ & $\begin{array}{l}\text { Nonprofit weekly wage premium of } 5 \% \\
\text { to } 10 \% \text { for child care workers in } \\
\text { federally regulated day care centers; no } \\
\text { difference for other centers. Results } \\
\text { consistent with the former being less } \\
\text { competitive and able to pay rents to } \\
\text { workers. }\end{array}$ & $\begin{array}{l}\text { Center characteristics, } \\
\text { labor quality, parental } \\
\text { participation, and } \\
\text { donations controlled for. } \\
\text { Some differences across } \\
\text { center types could persist. }\end{array}$ \\
\hline $\begin{array}{l}\text { Preston } \\
\text { (1989) }\end{array}$ & $\begin{array}{l}1990 \text { Survey of } \\
\text { Job Characteris- } \\
\text { tics (SJC); May } \\
1979 \text { Current } \\
\text { Population Survey } \\
\text { (CPS) }\end{array}$ & $\begin{array}{l}\text { OLS results for SJC imply negative } \\
\text { nonprofit differential of } \approx 20 \% \text { for } \\
\text { managers/professionals, no effect for } \\
\text { clerical workers; larger negative effects } \\
\text { for both groups in CPS. Selectivity- } \\
\text { corrected results sensitive to model } \\
\text { estimated. CPS wage change regressions } \\
\text { indicate no differential for clerical } \\
\text { workers, statistically insignificant } 10 \% \\
\text { premium for managers and professionals. } \\
\text { For-profit workers more often have } \\
\text { pensions, health insurance. }\end{array}$ & $\begin{array}{l}\text { SJC sample is small } \\
(\mathrm{n} \approx 300) \text {. Exclusion } \\
\text { restrictions are } \\
\text { questionable for } \\
\text { selectivity-corrected } \\
\text { estimates. Nonprofit } \\
\text { status inferred (not } \\
\text { observed) in CPS data. }\end{array}$ \\
\hline $\begin{array}{l}\text { Roomkin } \\
\text { and } \\
\text { Weisbrod } \\
\text { (1999) }\end{array}$ & $\begin{array}{l}\text { Hay Management } \\
\text { Consultants, } 1992 \\
\text { Hospital } \\
\text { Compensation } \\
\text { Survey }\end{array}$ & $\begin{array}{l}\text { Nonprofit hospitals offer higher base } \\
\text { salaries but lower bonus payments to six } \\
\text { top managerial positions. Total } \\
\text { compensation is higher in three and } \\
\text { lower in the other three. }\end{array}$ & $\begin{array}{l}\text { Job complexity,hospital } \\
\text { characteristics controlled } \\
\text { for; individual character- } \\
\text { istics are not. Low survey } \\
\text { response rate }(19 \%) \text {. }\end{array}$ \\
\hline $\begin{array}{l}\text { Shackett } \\
\text { and Tapani } \\
(1987)\end{array}$ & $\begin{array}{l}\text { National } \\
\text { Longitudinal } \\
\text { Surveys of Young } \\
\text { Men and Young } \\
\text { Women }\end{array}$ & $\begin{array}{l}\text { Compared to private nonregulated } \\
\text { industries, the nonprofit wage } \\
\text { differential is } 11,0,-14 \text {, and }-8 \text { percent } \\
\text { for white females, black females, white } \\
\text { males, and black males. }\end{array}$ & $\begin{array}{l}\text { Nonprofit status not } \\
\text { observed; instead it is } \\
\text { assumed to include all } \\
\text { persons in hospital and } \\
\text { educational services } \\
\text { industries. }\end{array}$ \\
\hline $\begin{array}{l}\text { Weisbrod } \\
(1983)\end{array}$ & $\begin{array}{l}\text { Same as } \\
\text { Goddeeris (1988) }\end{array}$ & $\begin{array}{l}\text { PIL lawyers earn } 20 \% \text { less annually than } \\
\text { if employed in private sector. These } \\
\text { attorneys are aware of the negative } \\
\text { earnings effects and expect them to be } \\
\text { permanent. Differences in preferences } \\
\text { consistent with type of employment. }\end{array}$ & $\begin{array}{l}\text { Small sample size (53 PIL } \\
\text { lawyers); PIL lawyers } \\
\text { may not be representative } \\
\text { of other attorneys in } \\
\text { nonprofits. Work hours } \\
\text { and fringe benefits not } \\
\text { controlled for. }\end{array}$ \\
\hline
\end{tabular}




\begin{tabular}{lcccc} 
& \multicolumn{2}{c}{$\begin{array}{c}\text { Industry Share } \\
\text { of Employment: }\end{array}$} & $\begin{array}{c}\text { \% of Industry } \\
\text { Employment in: }\end{array}$ \\
Industry & Overall & $\begin{array}{c}\text { Non- } \\
\text { profits }\end{array}$ & $\begin{array}{c}\text { Non- } \\
\text { profits }\end{array}$ & $\begin{array}{c}\text { For- } \\
\text { profits }\end{array}$ \\
& (a) & (b) & (c) & (d) \\
\hline Religious Organizations (880) & $0.7 \%$ & $10.4 \%$ & $85.1 \%$ & $14.9 \%$ \\
Social Services (861-871) & 2.2 & 15.1 & 39.6 & 37.1 \\
Hospitals (831) & 5.1 & 29.9 & 33.5 & 49.9 \\
Higher Education (850-860) & 2.5 & 8.1 & 18.3 & 21.8 \\
Nursing/Personal Care Facilities (832) & 1.5 & 3.5 & 13.4 & 76.8 \\
Other Professional (812-830,840,873,881-893) & 7.2 & 13.0 & 10.3 & 83.4 \\
Primary/Secondary Education (842) & 6.7 & 8.6 & 7.3 & 7.1 \\
Finance/Insurance/Real Estate (700-712) & 6.9 & 3.5 & 2.9 & 93.9 \\
Personal/Business Services (721-791) & 8.3 & 1.8 & 1.2 & 97.8 \\
Transportation/Communication/Utilities (400-472) & 8.3 & 1.5 & 1.0 & 79.5 \\
Wholesale/Retail Trade (500-691) & 17.0 & 1.3 & 0.4 & 99.0 \\
Agriculture/Mining/Construction (10-60) & 7.4 & 0.5 & 0.4 & 92.4 \\
Manufacturing (100-392) & 19.0 & 1.1 & 0.3 & 99.2 \\
Public Administration (900-932) & 5.9 & 0.0 & 0.0 & 0.0 \\
All Industries & 100.0 & 100.0 & 5.7 & 76.4 \\
\hline & & & & \\
\hline
\end{tabular}

Note: Data are from the 1994-1998 Current Population Survey Outgoing Rotation Groups for persons in their fourth interview month $(n=301,208)$; means are calculated using CPS sampling weights. The numbers in parentheses refer to three digit census industries. 
Table 2: Occupation Composition of Nonprofit Employment

\begin{tabular}{|c|c|c|c|c|}
\hline \multirow{2}{*}{ Occupation } & \multicolumn{2}{|c|}{$\begin{array}{l}\text { Occupation Share } \\
\text { of Employment: }\end{array}$} & \multicolumn{2}{|c|}{$\begin{array}{l}\text { \% of Occupation } \\
\text { Employment in: }\end{array}$} \\
\hline & $\begin{array}{c}\text { Overall } \\
\text { (a) }\end{array}$ & $\begin{array}{c}\text { Non- } \\
\text { profits } \\
\text { (b) }\end{array}$ & $\begin{array}{c}\text { Non- } \\
\text { profits } \\
\text { (c) } \\
\end{array}$ & $\begin{array}{c}\begin{array}{c}\text { For- } \\
\text { Profits }\end{array} \\
\text { (d) }\end{array}$ \\
\hline Health Professional $(15,83-106)$ & $4.2 \%$ & $18.5 \%$ & $25.4 \%$ & $58.2 \%$ \\
\hline Health Technician (203-208) & 1.6 & 5.0 & 17.5 & 70.5 \\
\hline Educator $(14,113-165)$ & 6.4 & 13.7 & 12.3 & 16.8 \\
\hline Other Professional $(4-13,17-79,173-199)$ & 20.7 & 26.7 & 7.4 & 75.6 \\
\hline Administrative Support (303-389) & 15.6 & 16.1 & 5.9 & 70.1 \\
\hline Service Worker (403-469) & 11.8 & 11.7 & 5.7 & 68.9 \\
\hline Farming/Fishing/Forestry (473-499) & 1.4 & 0.6 & 2.5 & 88.5 \\
\hline Non-Health Technician (209-235) & 2.2 & 0.9 & 2.3 & 82.6 \\
\hline Handlers/Cleaners/Laborers (863-889) & 3.5 & 0.8 & 1.2 & 92.4 \\
\hline Production/Craft/Repair (503-799) & 18.3 & 3.4 & 1.1 & 94.1 \\
\hline Sales (243-285) & 9.9 & 1.8 & 1.0 & 97.6 \\
\hline Transportation (803-859) & 4.4 & 0.7 & 0.9 & 88.1 \\
\hline All Occupations & 100.0 & 100.0 & 5.7 & 76.4 \\
\hline
\end{tabular}

Note: See note on Table 1. The numbers in parentheses refer to three digit census occupations. 
Table 3:

Weekly Wages and Demographic Characteristics By Sector of Employment

Industry/Characteris
Weekly Earnings (\$)

$\underline{\text { Full Sample }}$

$\$ 573$

$\$ 557$

$\$ 621$

$(\$ 1)$

(\$3)

(\$2)

$\underline{\text { Industry }}$

Social Services

$\$ 359$

(\$5)

Hospitals

$\$ 572$

(\$4)

Nursing Facilities

$\$ 360$

(\$4)

Education

$\$ 547$

(\$7)

Other Professional

$\$ 662$

(\$3)

$\$ 422$

$\$ 468$

(\$6)

(\$7)

$\$ 636$

$\$ 609$

(\$5)

$\$ 412$

(\$7)

$\$ 424$

(\$9)

$\$ 602$

(\$7)

$\$ 617$

(\$8)

(\$11)

$\$ 597$

(\$2)

$\$ 589$

(\$10)

$\underline{\text { Occupation }}$

Health Professional $\$ 762$

(\$5)

$\$ 487$

(\$4)

$\$ 556$

$(\$ 7)$

$\$ 864$

$\$ 767$

$\$ 761$

(\$7)

$\$ 513$

$(\$ 9)$

$\$ 550$

(\$8)

(\$2)

$\$ 594$

$\$ 721$

$(\$ 8)$

(\$3)

Other Professional

(\$2)

$\$ 647$

$\$ 774$

(\$6)

\section{Demographic Characteristics}

Education

High School Dropout

High School Graduate

Some College

College Graduate

Graduate Degree

$\begin{array}{lll}.116 & .039 & .035 \\ .363 & .189 & .236 \\ .283 & .290 & .269 \\ .178 & .273 & .258 \\ .060 & .210 & .201\end{array}$

(Table continues on next page) 
Table 3 (continued)

$\underline{\text { Marital Status }}$

Currently Married

.649

.649

.683

Never Married

.190

.199

.161

$\underline{\text { Race/Ethnicity }}$

Black

.110

.111

.162

Other Nonwhite

.046

.035

.042

Hispanic

.107

.045

.073

Other Characteristics

Age (years)

Male

Metropolitan Residence

Weekly Work Hours
38.2

.559

.780

40.9
39.8

.306

.787

38.2
40.7

.445

.753

39.7

Note: The top panel of the table shows average weekly earnings on the main job for respondents in year 1 of the 1994-1998 Current Population Survey Outgoing Rotation Groups, with standard errors in parentheses. The bottom panel shows mean values of selected demographic characteristics. CPS sampling weights are used in calculating all variable means. 
Table 4: Cross-sectional Estimates of Nonprofit Weekly Earnings Differential

\begin{tabular}{|c|c|c|c|c|c|c|}
\hline Group & $\begin{array}{c}\text { Sample } \\
\text { Size } \\
\end{array}$ & (a) & (b) & (c) & (d) & (e) \\
\hline All & 299,405 & $\begin{array}{l}-.122 \\
(.005)\end{array}$ & $\begin{array}{l}-.018 \\
(.005)\end{array}$ & $\begin{array}{l}-.148 \\
(.004)\end{array}$ & $\begin{array}{l}-.036 \\
(.005)\end{array}$ & $\begin{array}{c}.011 \\
(.004)\end{array}$ \\
\hline Males & 153,065 & $\begin{array}{l}-.217 \\
(.007)\end{array}$ & $\begin{array}{l}-.055 \\
(.009)\end{array}$ & $\begin{array}{l}-.217 \\
(.007)\end{array}$ & $\begin{array}{l}-.047 \\
(.008)\end{array}$ & $\begin{array}{l}-.033 \\
(.008)\end{array}$ \\
\hline Females & 146,340 & $\begin{array}{l}-.069 \\
(.006)\end{array}$ & $\begin{array}{c}.008 \\
(.006)\end{array}$ & $\begin{array}{l}-.120 \\
(.006)\end{array}$ & $\begin{array}{l}-.035 \\
(.006)\end{array}$ & $\begin{array}{c}.032 \\
(.005)\end{array}$ \\
\hline No College & 126,106 & $\begin{array}{l}-.160 \\
(.009)\end{array}$ & $\begin{array}{l}-.044 \\
(.010)\end{array}$ & $\begin{array}{l}-.136 \\
(.009)\end{array}$ & $\begin{array}{l}-.070 \\
(.009)\end{array}$ & $\begin{array}{c}6.9 \mathrm{E}-4 \\
(.009)\end{array}$ \\
\hline Attended College & 173,299 & $\begin{array}{l}-.118 \\
(.005)\end{array}$ & $\begin{array}{l}-.017 \\
(.006)\end{array}$ & $\begin{array}{l}-.154 \\
(.005)\end{array}$ & $\begin{array}{l}-.027 \\
(.006)\end{array}$ & $\begin{array}{c}.006 \\
(.005)\end{array}$ \\
\hline Whites & 254,029 & $\begin{array}{l}-.135 \\
(.005)\end{array}$ & $\begin{array}{l}-.029 \\
(.006)\end{array}$ & $\begin{array}{l}-.159 \\
(.005)\end{array}$ & $\begin{array}{l}-.042 \\
(.005)\end{array}$ & $\begin{array}{c}.002 \\
(.005)\end{array}$ \\
\hline Blacks & 29,455 & $\begin{array}{l}-.016 \\
(.014)\end{array}$ & $\begin{array}{c}.064 \\
(.015)\end{array}$ & $\begin{array}{l}-.044 \\
(.014)\end{array}$ & $\begin{array}{c}.031 \\
(.015)\end{array}$ & $\begin{array}{c}.072 \\
(.014)\end{array}$ \\
\hline Hispanics & 23,409 & $\begin{array}{l}-.071 \\
(.021) \\
\end{array}$ & $\begin{array}{c}.030 \\
(.024) \\
\end{array}$ & $\begin{array}{l}-.109 \\
(.021) \\
\end{array}$ & $\begin{array}{c}-7.5 \mathrm{E}-4 \\
(.023)\end{array}$ & $\begin{array}{c}.058 \\
(.021) \\
\end{array}$ \\
\hline \multicolumn{7}{|l|}{ Additional Controls } \\
\hline $\begin{array}{l}\text { Industry } \\
\text { Occupation } \\
\text { Weekly Work Hours }\end{array}$ & & $\begin{array}{l}\text { No } \\
\text { No } \\
\text { No }\end{array}$ & $\begin{array}{l}\text { Yes } \\
\text { No } \\
\text { No }\end{array}$ & $\begin{array}{l}\text { No } \\
\text { Yes } \\
\text { No }\end{array}$ & $\begin{array}{l}\text { Yes } \\
\text { Yes } \\
\text { No }\end{array}$ & $\begin{array}{l}\text { Yes } \\
\text { No } \\
\text { Yes }\end{array}$ \\
\hline
\end{tabular}

Note: The table shows the coefficient on a dummy variable indicating nonprofit status from a series of regressions where the dependent variable is the natural log of weekly earnings for the cross-sectional sample (in year 1). The equations also control for age and age squared, marital status (currently married and never married), race/ethnicity (black, Hispanic), education (high school graduate, some college, college graduate, post-graduate education), metropolitan residence, the survey year, and government employment. Columns (b), (d), and (e) add covariates for seven industry categories (hospitals, nursing/personal care facilities, social services, other professional, religious organizations, primary/secondary education, higher education); specifications (c) and (d) include dummy variables for six occupation categories (non-health professional, health professional, administrative support, educator, service worker, health technician); model (e) also controls for the number of hours worked per week. Standard errors are in parentheses. 
Table 5:

Average Changes in Log Wages As A Function of Employment Status in Years 1 and 2

\begin{tabular}{lccc} 
& All & $N \rightarrow P$ & $P \rightarrow N$ \\
\hline \multirow{2}{*}{ All } & & & \\
& {$[.062$} & .100 & .050 \\
Males & {$[106,633]$} & {$[1,224]$} & {$[1,087]$} \\
& .059 & .156 & .007 \\
Females & {$[54,039]$} & {$[379]$} & {$[321]$} \\
& .066 & .073 & .069 \\
No College & {$[52,593]$} & {$[845]$} & {$[766]$} \\
& .055 & .124 & .027 \\
Attended College & {$[41,914]$} & {$[330]$} & {$[309]$} \\
& & & .060 \\
Whites & {$[.067$} & .092 & {$[778]$} \\
& {$[64,719]$} & {$[894]$} & .043 \\
Blacks & .062 & .105 & {$[913]$} \\
& {$[91,865]$} & {$[1,038]$} & .059 \\
Hispanics & .066 & .058 & {$[131]$} \\
& {$[9,807]$} & {$[138]$} & -.037 \\
& & & {$[54]$} \\
\hline
\end{tabular}

Note: The table shows (weighted) average changes in log wages, as a function of employment status in years 1 and 2 for the ORG panel sample of persons matched in each year. The first column displays the average change in (log) wages between years 1 and 2 for all sample members. The second and third columns indicate corresponding wage changes for persons transitioning between the nonprofit and for-profit sectors, over the two years, and changing three digit industries or occupations. Sample sizes are shown in brackets. 
Table 6: Alternative Estimates of Nonprofit Earnings Differential Using Panel Sample

\begin{tabular}{|c|c|c|c|c|c|c|c|c|c|}
\hline \multirow[t]{2}{*}{ Group } & \multirow{2}{*}{$\begin{array}{c}\text { Sample } \\
\text { Size }\end{array}$} & \multicolumn{3}{|c|}{ Wage Level in Year 1} & \multicolumn{3}{|c|}{$\begin{array}{c}\text { Symmetric } \\
\text { Wage Change }\end{array}$} & \multicolumn{2}{|c|}{$\begin{array}{c}\text { Asymmetric } \\
\text { Wage Change }\end{array}$} \\
\hline & & (a) & (b) & (c) & (a) & (b) & (c) & $N \rightarrow P$ & $P \rightarrow N$ \\
\hline All & 106,633 & $\begin{array}{l}-.121 \\
(.007)\end{array}$ & $\begin{array}{l}-.013 \\
(.008)\end{array}$ & $\begin{array}{l}.013 \\
(.007)\end{array}$ & $\begin{array}{l}-.026 \\
(.009)\end{array}$ & $\begin{array}{l}-.026 \\
(.009)\end{array}$ & $\begin{array}{l}-.022 \\
(.008)\end{array}$ & $\begin{array}{l}-.035 \\
(.014)\end{array}$ & $\begin{array}{l}-.016 \\
(.014)\end{array}$ \\
\hline Males & 54,039 & $\begin{array}{l}-.222 \\
(.012)\end{array}$ & $\begin{array}{l}-.059 \\
(.014)\end{array}$ & $\begin{array}{l}-.039 \\
(.013)\end{array}$ & $\begin{array}{l}-.085 \\
(.016)\end{array}$ & $\begin{array}{l}-.082 \\
(.016)\end{array}$ & $\begin{array}{l}-.081 \\
(.015)\end{array}$ & $\begin{array}{l}-.107 \\
(.026)\end{array}$ & $\begin{array}{l}-.070 \\
(.026)\end{array}$ \\
\hline Females & 52,594 & $\begin{array}{l}-.067 \\
(.009)\end{array}$ & $\begin{array}{c}.017 \\
(.010)\end{array}$ & $\begin{array}{l}.036 \\
(.008)\end{array}$ & $\begin{array}{l}7.3 \mathrm{E}-4 \\
(.011)\end{array}$ & $\begin{array}{c}5.3 \mathrm{E}-4 \\
(.011)\end{array}$ & $\begin{array}{c}.006 \\
(.010)\end{array}$ & $\begin{array}{c}.001 \\
(.017)\end{array}$ & $\begin{array}{c}.004 \\
(.017)\end{array}$ \\
\hline No College & 41,914 & $\begin{array}{l}-.155 \\
(.014)\end{array}$ & $\begin{array}{l}-.026 \\
(.016)\end{array}$ & $\begin{array}{c}.011 \\
(.014)\end{array}$ & $\begin{array}{l}-.042 \\
(.017)\end{array}$ & $\begin{array}{l}-.045 \\
(.017)\end{array}$ & $\begin{array}{l}-.032 \\
(.016)\end{array}$ & $\begin{array}{l}-.050 \\
(.028)\end{array}$ & $\begin{array}{l}-.018 \\
(.028)\end{array}$ \\
\hline Attended College & 64,719 & $\begin{array}{l}-.117 \\
(.008)\end{array}$ & $\begin{array}{l}-.015 \\
(.009)\end{array}$ & $\begin{array}{c}.005 \\
(.008)\end{array}$ & $\begin{array}{l}-.021 \\
(.010)\end{array}$ & $\begin{array}{l}-.019 \\
(.011)\end{array}$ & $\begin{array}{l}-.018 \\
(.011)\end{array}$ & $\begin{array}{l}-.030 \\
(.017)\end{array}$ & $\begin{array}{l}-.015 \\
(.017)\end{array}$ \\
\hline Whites & 91,865 & $\begin{array}{l}-.134 \\
(.008)\end{array}$ & $\begin{array}{l}-.025 \\
(.009)\end{array}$ & $\begin{array}{c}.001 \\
(.008)\end{array}$ & $\begin{array}{l}-.037 \\
(.009)\end{array}$ & $\begin{array}{l}-.035 \\
(.009)\end{array}$ & $\begin{array}{l}-.033 \\
(.009)\end{array}$ & $\begin{array}{l}-.043 \\
(.015)\end{array}$ & $\begin{array}{l}-.019 \\
(.015)\end{array}$ \\
\hline Blacks & 9,807 & $\begin{array}{l}-.019 \\
(.023)\end{array}$ & $\begin{array}{c}.063 \\
(.025)\end{array}$ & $\begin{array}{c}.073 \\
(.023)\end{array}$ & $\begin{array}{c}.022 \\
(.029)\end{array}$ & $\begin{array}{c}.018 \\
(.029)\end{array}$ & $\begin{array}{c}.022 \\
(.028)\end{array}$ & $\begin{array}{c}.052 \\
(.051)\end{array}$ & $\begin{array}{c}.027 \\
(.046)\end{array}$ \\
\hline Hispanics & 7,336 & $\begin{array}{l}-.076 \\
(.035)\end{array}$ & $\begin{array}{l}.056 \\
(.040)\end{array}$ & $\begin{array}{l}.079 \\
(.036)\end{array}$ & $\begin{array}{l}-.081 \\
(.039)\end{array}$ & $\begin{array}{l}-.086 \\
(.039)\end{array}$ & $\begin{array}{l}-.060 \\
(.038)\end{array}$ & $\begin{array}{l}-.081 \\
(.067)\end{array}$ & $\begin{array}{l}-.048 \\
(.063)\end{array}$ \\
\hline
\end{tabular}


Note: See notes on table 4. All specifications include controls for age and age squared, marital status, race/ethnicity, education, metropolitan residence, the survey year, and dummy variables indicating employment in government jobs or corresponding transitions into or out of government positions. Column (b) adds controls for the seven industry categories and model (c) also holds constant weekly work hours (in the wage levels equations) or the change in work hours (in the change specifications). The wage level models show the nonprofit differential from estimates of: $\mathrm{W}_{\mathrm{i} 1}=\mathrm{X}_{\mathrm{i} 1} \beta+\mathrm{N}_{\mathrm{i} 1} \gamma+\varepsilon_{\mathrm{i} 1}$, where $\mathrm{N}_{\mathrm{i} 1}$ is a dummy variable indicating whether respondent $\mathrm{i}$ works for a nonprofit employer in year 2. The symmetric wage change equations take the form: $\mathrm{W}_{\mathrm{i} 2}-\mathrm{W}_{\mathrm{i} 1}=\mathrm{X}_{\mathrm{i} 2} \beta+\left(\mathrm{N}_{\mathrm{i} 2}-\mathrm{N}_{\mathrm{i} 1}\right) \gamma+$ $\varepsilon_{\mathrm{i}}$; the table displays $\hat{\gamma}$. The asymmetric specifications are: $\mathrm{W}_{\mathrm{i} 2}-\mathrm{W}_{\mathrm{i} 1}=\mathrm{X}_{\mathrm{i} 2} \beta+\mathrm{NP}_{\mathrm{i}} \gamma_{1}+\mathrm{PN}_{\mathrm{i}} \gamma_{2}+\varepsilon_{\mathrm{i}}$, where $\mathrm{NP}_{\mathrm{i}}\left(\mathrm{PN}_{\mathrm{i}}\right)$ is a dummy variable indicating movement nonprofit to for-profit (for-profit to nonprofit) employers between years 1 and 2. The table displays $-\hat{\gamma}_{1}$ and $\hat{\gamma}_{2}$ for specification (c), with controls for industry and work hours. 
Table 7: Employment Transitions and Nonprofit Earnings Differentials Among Displaced Workers

\begin{tabular}{|c|c|c|c|c|c|c|c|c|c|}
\hline \multirow{3}{*}{ Group } & \multirow{3}{*}{$\begin{array}{c}\text { Sample } \\
\text { Size }\end{array}$} & & & & & \multicolumn{4}{|c|}{ Nonprofit Differential } \\
\hline & & \multicolumn{4}{|c|}{ Transition Hazard Rates } & \multicolumn{2}{|c|}{ Wage Level } & \multicolumn{2}{|c|}{ Wage Changes } \\
\hline & & $N \rightarrow N$ & $N \rightarrow P$ & $P \rightarrow P$ & $P \rightarrow N$ & (a) & (b) & (a) & (b) \\
\hline All & 5,381 & .285 & .571 & .919 & .030 & $\begin{array}{l}-.015 \\
(.044)\end{array}$ & $\begin{array}{c}.042 \\
(.051)\end{array}$ & $\begin{array}{l}-.044 \\
(.033)\end{array}$ & $\begin{array}{c}.005 \\
(.035)\end{array}$ \\
\hline Males & 3,055 & .199 & 642 & .940 & .020 & $\begin{array}{l}-.050 \\
(.075)\end{array}$ & $\begin{array}{c}.010 \\
(.088)\end{array}$ & $\begin{array}{l}-.080 \\
(.052)\end{array}$ & $\begin{array}{l}-.031 \\
(.055)\end{array}$ \\
\hline Females & 2,326 & .319 & .542 & .888 & .044 & $\begin{array}{l}.008 \\
(.055)\end{array}$ & $\begin{array}{c}.052 \\
(.064)\end{array}$ & $\begin{array}{l}-.015 \\
(.044)\end{array}$ & $\begin{array}{c}.041 \\
(.046)\end{array}$ \\
\hline No College & 2,287 & .208 & .734 & .947 & .017 & $\begin{array}{l}-.074 \\
(.086)\end{array}$ & $\begin{array}{l}7.2 \mathrm{E}-4 \\
(.097)\end{array}$ & $\begin{array}{l}-.087 \\
(.062)\end{array}$ & $\begin{array}{l}-.065 \\
(.065)\end{array}$ \\
\hline Attended College & 3,094 & .309 & .518 & .900 & .040 & $\begin{array}{l}-.007 \\
(.052)\end{array}$ & $\begin{array}{c}.050 \\
(.061)\end{array}$ & $\begin{array}{l}-.022 \\
(.040)\end{array}$ & $\begin{array}{c}.036 \\
(.042)\end{array}$ \\
\hline Whites & 4,734 & .274 & .580 & .923 & .030 & $\begin{array}{l}-.014 \\
(.047)\end{array}$ & $\begin{array}{l}.045 \\
(.054)\end{array}$ & $\begin{array}{l}-.049 \\
(.035)\end{array}$ & $\begin{array}{c}.001 \\
(.037)\end{array}$ \\
\hline Blacks & 409 & .300 & .558 & .875 & .034 & $\begin{array}{l}-.076 \\
(.141)\end{array}$ & $\begin{array}{l}-.027 \\
(.176)\end{array}$ & $\begin{array}{c}.038 \\
(.106)\end{array}$ & $\begin{array}{c}.038 \\
(.106)\end{array}$ \\
\hline Hispanics & 444 & .039 & .961 & .951 & .026 & $\begin{array}{c}.187 \\
(.203)\end{array}$ & $\begin{array}{c}.148 \\
(.224)\end{array}$ & $\begin{array}{l}-.065 \\
(.105)\end{array}$ & $\begin{array}{l}-.028 \\
(.128)\end{array}$ \\
\hline
\end{tabular}


Notes: See notes on tables 4 and 6. Data are for job losers from the 1994, 1996, and 1998 Displaced Worker Supplements to the February CPS who report weekly wages in both the pre- and post-displacement jobs. The transition hazard rates indicate the probability of holding a specified type of post-displacement employment conditional on the class of the predisplacement job (e.g. $N \rightarrow N$ indicates the probability of working in a nonprofit job at the survey date conditional on having worked for a nonprofit employer prior to displacement). These probabilities are calculated using DWS sampling weights. The wage level models show $\hat{\gamma}$ from estimates of: $\mathrm{W}_{\mathrm{id}}=\mathrm{X}_{\mathrm{i}} \beta+\mathrm{N}_{\mathrm{id}} \gamma+\varepsilon_{\mathrm{i}}$, where the subscript $\mathrm{d}$ indicates the predisplacement job; (these are predisplacement differentials). The wage change equations take the form: $\mathrm{W}_{\mathrm{is}}-\mathrm{W}_{\mathrm{id}}=\mathrm{X}_{\mathrm{i}} \beta+\left(\mathrm{N}_{\mathrm{is}}-\mathrm{N}_{\mathrm{id}}\right) \gamma+\varepsilon_{\mathrm{i}}$, where the s subscript indicates the survey date and all of the covariates refer to values at this date; the table displays $\hat{\gamma}$. All of the models also control for age and age squared, marital status, race/ethnicity, education, metropolitan residence, the survey year, and government employment. Specification (b) includes controls for the industry of employment, whereas specification (a) does not. 
Table 8: Nonprofit Earnings Differentials for Specific Industries

\begin{tabular}{|c|c|c|c|c|c|c|c|c|c|}
\hline \multirow[b]{3}{*}{ Industry } & \multicolumn{6}{|c|}{ Wage Levels in Year 1} & \multicolumn{3}{|c|}{$\begin{array}{c}\text { Wage Changes } \\
\text { (Industry Stayers Only) }\end{array}$} \\
\hline & \multicolumn{3}{|c|}{ Cross-sectional Data Set } & \multicolumn{3}{|c|}{ Panel Data Set } & \multirow[b]{2}{*}{$\begin{array}{l}\text { Sample } \\
\text { Size }\end{array}$} & \multirow[b]{2}{*}{ (a) } & \multirow[b]{2}{*}{ (b) } \\
\hline & $\begin{array}{l}\text { Sample } \\
\text { Size }\end{array}$ & (a) & (b) & $\begin{array}{l}\text { Sample } \\
\text { Size }\end{array}$ & (a) & (b) & & & \\
\hline Hospitals & 15,660 & $\begin{array}{l}.041 \\
(.009)\end{array}$ & $\begin{array}{l}.032 \\
(.008)\end{array}$ & 6,116 & $\begin{array}{l}.063 \\
(.014)\end{array}$ & $\begin{array}{l}.055 \\
(.013)\end{array}$ & 5,168 & $\begin{array}{l}5.2 \mathrm{E}-4 \\
(.023)\end{array}$ & $\begin{array}{l}-.003 \\
(.022)\end{array}$ \\
\hline Nursing Facilities & 4,699 & $\begin{array}{l}.022 \\
(.021)\end{array}$ & $\begin{array}{l}.049 \\
(.018)\end{array}$ & 1,583 & $\begin{array}{l}.022 \\
(.036)\end{array}$ & $\begin{array}{l}.038 \\
(.030)\end{array}$ & 1,111 & $\begin{array}{l}.167 \\
(.066)\end{array}$ & $\begin{array}{l}.164 \\
(.061)\end{array}$ \\
\hline Social Services & 6,646 & $\begin{array}{c}.038 \\
(.018)\end{array}$ & $\begin{array}{c}.108 \\
(.015)\end{array}$ & 2,279 & $\begin{array}{c}.040 \\
(.031)\end{array}$ & $\begin{array}{c}.093 \\
(.024)\end{array}$ & 1,427 & $\begin{array}{l}-.042 \\
(.044)\end{array}$ & $\begin{array}{l}-.044 \\
(.041)\end{array}$ \\
\hline
\end{tabular}

Notes: See notes on Tables 4 and 6. The wage levels are calculated for year 1. Wages changes refer to the panel data set for persons remaining in the same industry in years 1 and 2. All specifications include controls for age and age squared, marital status,

race/ethnicity, education, metropolitan residence, the survey year, and dummy variables indicating employment in government jobs.

Specification (b) also holds constant weekly work hours or changes in hours. 